\title{
Short-term effects of spermine ingestion on the small intestine: a comparison of suckling and weaned rats
}

\author{
Olivier Peulen, Patricia Deloyer, Guy DANDRIFOSSE* \\ Department of Biochemistry and general Physiology, University of Liege, \\ Institute of Chemistry B6c, 4000 Sart-Tilman, Belgium
}

(Received 18 November 2003; accepted 7 April 2004)

\begin{abstract}
We have previously shown that spermine, shortly after its ingestion, can induce the alteration of the morphology of the small intestine of suckling rats. It was proposed that this alteration is due to polyamine accumulation inside the epithelial cells. This could also be related to the fact that the intestine of the suckling rat is in an immature state. To shed light on this issue, disaccharidase and alkaline phosphatase activity assays, protein, DNA and RNA content measurements and polyamine concentration analysis were performed on the small intestine of suckling and weaned Wistar rats treated with spermine. Spermine did not induce the same intestinal alterations in weaned rats compared to suckling animals. Indeed, in sucklings, spermine administration induced a decrease of the protein, DNA, putrescine and spermidine intestinal content, suggesting a cell loss. The cell loss impaired the activity of intestinal enzymes: lactase, maltase and alkaline phosphatase. In weaned rats, the same treatment did not alter these parameters. Exogenous spermine by itself is not sufficient to induce the alterations described here and previously. The maturity degree of the small intestine could be the basis of this process.
\end{abstract}

spermine / suckling rat / weaned rat / cell loss / maturation / differentiation

\section{INTRODUCTION}

We have previously shown that exogenous spermine can induce morphological and biochemical modifications in the small intestine of suckling rats [1-3]. One of the morphological changes observed is a decrease of the villous height, confirmed by a decrease of specific activities (SA) of disaccharidases as lactase and maltase. Sometimes this modification is accompanied by a decrease of DNA and protein content of the small intestine [3]. At this time, we know that these alterations are not due to cytotoxic products coming from the metabolisation of spermine by polyamine oxidase [3], are not reduced by cyclosporine A [4], and are diminished by a zinc chelator (metalloproteinase inhibitor): o-phenanthroline [5]. It has been suggested that the alteration observed could be due to polyamine accumulation inside the cells. We hypothesise here that the state of maturation of the small intestine plays a role in this phenomenon. This study was performed to determine whether the intestinal cells from weaned rats have the same sensitivity to spermine as those from suckling rats. Further studies, based on

* Corresponding author: g.dandrifosse@ulg.ac.be 
genomic and proteomic technologies, will allow us to understand the mechanisms inducing these alterations.

\section{MATERIALS AND METHODS}

\subsection{Animals}

Wistar rats, housed in an air-conditioned room at $23^{\circ} \mathrm{C}$ with a 12 -h (h) light-dark cycle, were used throughout the study. They were fed with A03 $10 \mathrm{~mm}$ pellets (Animalabo, Brussels, Belgium) and had water ad libitum. The litters were reduced to 10 pups per lactating mother with free access between the mother and pups. The day of birth was designated as day 0 and at day 21 the animals were separated from the mother. In our experiments, no distinction between genders was made, as no body weight difference exists between male or female pups. Since it is known that experimental values may vary from one litter to another, the comparisons of the results were always made between animals from the same litter.

The animal welfare committees of the University of Liege and of the FRSM ("Fonds de la Recherche Scientifique Médicale") approved the animal experiments.

\subsection{Chemicals and equipment}

All chemicals were bought from Sigma Chemical Co. (St Louis, Mo, USA) or from Merck (Darmstad, Germany). The spectrophotometer (Ultrospec plus) was from LKB. The HPLC system was from Merck-Hitachi as well as the HPLC column (Lichrocart).

\subsection{Treatments}

Spermine tetrahydrochloride was dissolved in $50 \mu \mathrm{L}$ of water ( $\alpha \mathrm{Q}$ system, Millipore) for pups (11-day-old) and in $100 \mu \mathrm{L}$ for older rats (18-, 20-, 22- or 31-day-old). It was administered orally $\left(0.4 \mu \mathrm{mol} \cdot \mathrm{g}^{-1}\right.$ body weight) as reported before [6]. Control ani- mals of the same age were treated in the same way, but received only the vehicle.

Six hours after spermine ingestion, the animals were killed by beheading. The small intestine was immediately removed. The duodenum was removed and the remains of the small intestine were divided into two equal parts, the jejunum and the ileum. Each part of the small intestine was flushed with $10 \mathrm{~mL}$ cold saline $\left(\mathrm{NaCl} 9 \mathrm{~g} \cdot \mathrm{L}^{-1} ; 4^{\circ} \mathrm{C}\right)$ during $2 \mathrm{~min}$, then homogenised in distilled water $\left(1 \mathrm{~g}\right.$ wet weight $\left.4.15 \mathrm{~mL}^{-1}\right)$, using a homogeniser (ultra-turrax, Ika). The lumen contents and the homogenates of each parts of the small intestine were kept in portions maintained at $-70{ }^{\circ} \mathrm{C}$ until analysis.

\subsection{Protein content analysis}

The protein content of the homogenates was estimated by Bradford's method [7], using bovine serum albumin as the protein standard. The results are expressed as $\mathrm{mg}$ protein per g wet weight of the organ or as mg per organ.

\subsection{Disaccharidase activity analysis}

Sucrase (EC 3.2.1.48), maltase (EC 3.2.1.20) and lactase (EC 3.2.1.23) activities were assayed according to Dahlqvist [8]. Enzyme specific activities (SA) were expressed as $\mu \mathrm{mol}$ substrate hydrolysed per min and per $\mathrm{g}$ of intestinal proteins.

\subsection{Alkaline phosphatase activity analysis}

Alkaline phosphatase (EC 3.1.3.1) was assayed according to Millington [9]. Enzyme specific activities (SA) were expressed as $\mu \mathrm{mol}$ substrate hydrolysed per min and per $\mathrm{g}$ of intestinal proteins.

\subsection{DNA and RNA content analysis}

DNA and RNA content were estimated by Schneider's procedure [10], using calf thymus DNA or yeast RNA as the standard. 
Table I. Short-term effects of spermine administration in suckling (11-day-old) rats: protein, DNA and RNA content of the small intestine $6 \mathrm{~h}$ after spermine ingestion.

\begin{tabular}{|c|c|c|c|c|c|c|c|}
\hline & & \multirow{2}{*}{$\begin{array}{c}\text { Protein } \\
\mathrm{mg} \cdot \mathrm{g}^{-1} \text { wet } \\
\text { weight }\end{array}$} & \multicolumn{2}{|c|}{ DNA } & \multicolumn{2}{|c|}{ RNA } & \multirow[b]{2}{*}{ RNA/DNA } \\
\hline & & & $\begin{array}{l}\mathrm{mg} \cdot \mathrm{g}^{-1} \text { wet } \\
\text { weight }\end{array}$ & $\begin{array}{l}\mathrm{mg} \cdot \mathrm{g}^{-1} \\
\text { protein }\end{array}$ & $\begin{array}{c}\mathrm{mg} \cdot \mathrm{g}^{-1} \\
\text { wet weight }\end{array}$ & $\begin{array}{l}\mathrm{mg} \cdot \mathrm{g}^{-1} \\
\text { protein }\end{array}$ & \\
\hline \multirow[t]{2}{*}{ Jejunum } & Control $(\mathrm{n}=3)$ & $114.5 \pm 2.9$ & $5.9 \pm 1.2$ & $51.7 \pm 11.6$ & $2.4 \pm 0.7$ & $20.9 \pm 6.1$ & $0.4 \pm 0.2$ \\
\hline & SPM-treated $(n=3)$ & $95.1 \pm 10.1 *$ & $5.4 \pm 1.0$ & $57.9 \pm 16.7$ & $2.8 \pm 0.9$ & $28.8 \pm 7.0$ & $0.5 \pm 0.3$ \\
\hline \multirow[t]{2}{*}{ Ileum } & Control $(\mathrm{n}=3)$ & $128.4 \pm 11.8$ & $6.9 \pm 2.6$ & $55.1 \pm 24.2$ & $2.1 \pm 0.5$ & $16.1 \pm 3.4$ & $0.3 \pm 0.1$ \\
\hline & SPM-treated $(n=3)$ & $100.0 \pm 20.6$ & $6.7 \pm 0.5$ & $69.8 \pm 19.5$ & $2.0 \pm 0.3$ & $20.0 \pm 1.5$ & $0.3 \pm 0.1$ \\
\hline
\end{tabular}

$\mathrm{SPM}=$ spermine; the results are expressed as mean \pm S.D.; $* P<0.05$.

The results are expressed as mg DNA or RNA per $g$ of organ wet weight, as mg per $\mathrm{g}$ of intestinal protein, as $\mathrm{mg}$ per organ or as RNA/DNA ratio.

\subsection{Polyamine content}

The polyamine content was measured by HPLC [11]. The polyamines were dansylated [12] and subsequently separated on a reversed-phase column. The results were expressed as nmol per $g$ wet weight, as $\mu \mathrm{mol}$ per g intestinal protein or as nmol per organ. Alternatively, polyamines were expressed as nmol per mg DNA or RNA, or as the spermidine-spermine ratio. The jejunal and ileal contents were freezed-dried; then polyamine content was analysed as described above. The results of the jejunum and the ileum were combined and expressed as nmol. The percentage of polyamine in the ileum was calculated.

\subsection{Statistical analysis}

The results are reported as means with their standard deviation (SD). A statistical comparison between groups was performed using a Student $t$-test for independent samples or the Student-Newman-Keuls method. The Mann-Whitney $U$ test was used when heteroscedasticity was suspected.

\section{RESULTS}

\subsection{Spermine administration to suckling rats}

In suckling rats, $6 \mathrm{~h}$ after spermine administration, body weight $(18.25 \pm 1.50 \mathrm{~g}$ in control vs. $16.83 \pm 1.04 \mathrm{~g}$ in treated; $n=3$ ) remained unchanged $(P=0.223)$, but jejunum $(0.287 \pm 0.018 \mathrm{~g}$ in control vs. $0.168 \pm$ $0.027 \mathrm{~g}$ in treated, $n=3)$ and ileum $(0.231 \pm$ $0.022 \mathrm{~g}$ in control vs. $0.116 \pm 0.003 \mathrm{~g}$ in treated, $n=3$ ) weight were significantly reduced (respectively $P=0.001$ and $P=$ $0.034, n=3$ ).

In these 11-day-old rats, the protein content of the small intestine, expressed as a quantity per wet weight of the organ, was reduced $(P=0.013$ in jejunum). DNA and RNA contents expressed as a quantity per wet weight of the organ or as a quantity per $\mathrm{g}$ protein, and RNA/DNA ratio remained unchanged (Tab. I).

In parallel, spermine administration induced a significant decrease of lactase and maltase SA in the jejunum and in the ileum as early as $6 \mathrm{~h}$ after the beginning of the treatment (Fig. 1). In the jejunum, sucrase SA was higher in treated suckling rats than in control animals of the same age. In the ileum, spermine treatment induced a significant decrease of alkaline phosphatase SA. 

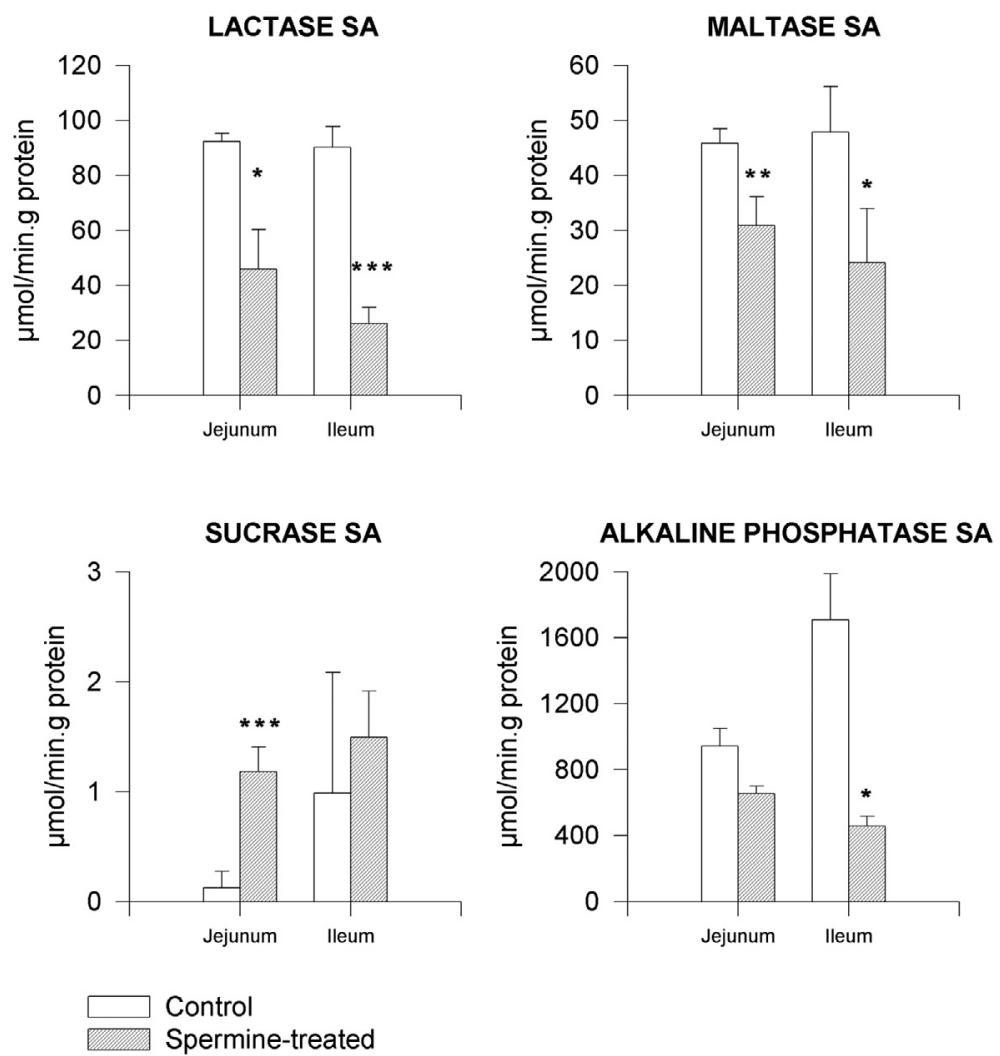

Figure 1. Disaccharidase and alkaline phosphatase SA in the small intestine of suckling (11- dayold) rats $6 \mathrm{~h}$ after spermine ingestion $(n=3)$. The results are expressed as mean $\pm \mathrm{SD}$; $* P<0.05$; ** $P<0.01 ; * * * P<0.001$.

In the jejunum and in the ileum of spermine-treated suckling rats, the putrescine content of the small intestine, expressed as nmol per $g$ wet weight or as $\mu$ mol per $g$ protein was not significantly reduced, as compared to control pups (Tab. II). Spermidine content of the small intestine, expressed as nmol per $g$ wet weight or as $\mu$ mol per $g$ protein, was not significantly reduced in the jejunum. In the ileum, a significant increase of spermidine content, expressed as $\mu \mathrm{mol}$ per $g$ protein, was observed after spermine ingestion. This content remained unchanged when expressed as nmol per $\mathrm{g}$ wet weight. Spermine content was not significantly different between the two groups when expressed as nmol per $\mathrm{g}$ wet weight $(P=0.059$ in the jejunum and $P=0.064$ in the ileum). The spermine content in the jejunum as well as in the ileum, expressed as $\mu \mathrm{mol}$ per $\mathrm{g}$ protein, was significantly higher (2-fold increase) in spermine-treated rats as compared to controls. In the lumen of the small intestine, putrescine and spermidine were mainly located in the ileum and were not affected by spermine administration. In the controls, spermine was mainly located in the jejunum. Spermine ingestion led to a significant modification of the localisation of this polyamine. Moreover, spermine administration significantly increased the polyamine content in the small intestine lumen. 
Table II. Short-term effects of spermine administration in suckling (11-day-old) rats: polyamine content of the small intestine $6 \mathrm{~h}$ after spermine ingestion.

\begin{tabular}{|c|c|c|c|c|c|c|c|}
\hline & & \multicolumn{2}{|c|}{ Putrescine } & \multicolumn{2}{|c|}{ Spermidine } & \multicolumn{2}{|c|}{ Spermine } \\
\hline & & $\begin{array}{l}\text { nmol.g }{ }^{-1} \text { wet } \\
\text { weight }\end{array}$ & $\begin{array}{l}\mu \mathrm{mol} \cdot \mathrm{g}^{-1} \\
\text { protein }\end{array}$ & $\begin{array}{l}\text { nmol.g }{ }^{-1} \text { wet } \\
\text { weight }\end{array}$ & $\begin{array}{l}\mu \mathrm{mol} \cdot \mathrm{g}^{-1} \\
\text { protein }\end{array}$ & $\begin{array}{c}\text { nmol.g }{ }^{-1} \text { wet } \\
\text { weight }\end{array}$ & $\begin{array}{c}\mu \mathrm{mol} \cdot \mathrm{g}^{-1} \\
\text { protein }\end{array}$ \\
\hline \multirow[t]{2}{*}{ Jejunum } & $\begin{array}{l}\text { Control } \\
(n=3)\end{array}$ & $372.2 \pm 17.6$ & $3.2 \pm 0.2$ & $1070 \pm 217$ & $9.2 \pm 2.0$ & $731 \pm 159$ & $6.3 \pm 1.5$ \\
\hline & $\begin{array}{l}\text { SPM-treated } \\
\quad(n=3)\end{array}$ & $250.8 \pm 84.4$ & $2.6 \pm 0.6$ & $768 \pm 71$ & $8.1 \pm 0.7$ & $1162 \pm 236$ & $12.3 \pm 2.9^{*}$ \\
\hline \multirow[t]{3}{*}{ Ileum } & $\begin{array}{l}\text { Control } \\
(\mathrm{n}=3)\end{array}$ & $464.2 \pm 152.9$ & $3.7 \pm 1.2$ & $1569 \pm 69$ & $12.3 \pm 0.9$ & $816 \pm 251$ & $6.3 \pm 1.5$ \\
\hline & $\begin{array}{l}\text { SPM-treated } \\
\quad(n=3)\end{array}$ & $232.1 \pm 174.4$ & $1.1 \pm 0.9$ & $1425 \pm 313$ & $15.8 \pm 0.9^{*}$ & $1357 \pm 29$ & $15.3 \pm 2.2^{*}$ \\
\hline & & nmol & $\%$ in ileum & nmol & $\%$ in ileum & nmol & $\%$ in ileum \\
\hline \multirow[t]{2}{*}{ Lumen } & $\begin{array}{l}\text { Control } \\
(n=3)\end{array}$ & $0.20 \pm 0.12$ & 100 & $0.07 \pm 0.05$ & $88.14 \pm 20.54$ & $1.07 \pm 0.14$ & $34.54 \pm 7.31$ \\
\hline & $\begin{array}{l}\text { SPM-treated } \\
\quad(n=3)\end{array}$ & $0.13 \pm 0.02$ & 100 & $0.10 \pm 0.03$ & $84.22 \pm 22.14$ & $17.33 \pm 2.45^{* * *}$ & $74.25 \pm 4.99 * *$ \\
\hline
\end{tabular}

$\mathrm{SPM}=$ spermine; the results are expressed as mean \pm S.D.; $* P<0.05$, ** $P<0.01, * * * P<0.001$.

Table III. Short-term effects of spermine administration in suckling (11-day-old) rats: quantity of protein, DNA, RNA, putrescine, spermidine and spermine per organ $6 \mathrm{~h}$ after spermine ingestion.

\begin{tabular}{|c|c|c|c|c|c|c|c|}
\hline & & $\begin{array}{c}\text { Protein } \\
\mathrm{mg} \cdot \text { organ }^{-1}\end{array}$ & $\begin{array}{c}\text { DNA } \\
\text { mg.organ }\end{array}$ & $\begin{array}{c}\text { RNA } \\
\mathrm{mg} \cdot \text { organ }^{-1}\end{array}$ & $\begin{array}{c}\text { Putrescine } \\
\text { nmol·organ }^{-1}\end{array}$ & $\begin{array}{c}\text { Spermidine } \\
\text { nmol·organ }^{-1}\end{array}$ & $\begin{array}{c}\text { Spermine } \\
\text { nmol.organ }^{-1}\end{array}$ \\
\hline \multirow[t]{2}{*}{ Jejunum } & Control $(\mathrm{n}=3)$ & $32.91 \pm 0.01$ & $1.70 \pm 0.43$ & $0.69 \pm 0.22$ & $107.7 \pm 10.5$ & $310.8 \pm 72.2$ & $213.8 \pm 62.6$ \\
\hline & $\begin{array}{c}\text { SPM-treated } \\
\quad(n=3)\end{array}$ & $15.92 \pm 0.02 * * *$ & $0.92 \pm 0.31 *$ & $0.46 \pm 0.13$ & $41.3 \pm 11.3^{* *}$ & $128.3 \pm 8.2 *$ & $199.2 \pm 64.7$ \\
\hline \multirow[t]{2}{*}{ Ileum } & Control $(n=3)$ & $29.81 \pm 5.18$ & $1.55 \pm 0.44$ & $0.48 \pm 0.16$ & $102.9 \pm 28.2$ & $353.7 \pm 47.4$ & $187.5 \pm 78.8$ \\
\hline & $\begin{array}{l}\text { SPM-treated } \\
\quad(n=3)\end{array}$ & $11.68 \pm 2.65^{* *}$ & $0.78 \pm 0.04 *$ & $0.23 \pm 0.04^{*}$ & $12.0 \pm 11.3^{*}$ & $165.7 \pm 42.8^{*}$ & $157.2 \pm 9.6$ \\
\hline
\end{tabular}

$\mathrm{SPM}=$ spermine; the results are expressed as mean \pm S.D.; $* P<0.05 ; * * P<0.01 ; * * * P<0.001$.

When expressed as a weight per organ, protein, DNA, putrescine and spermidine decreased significantly in the jejunum of the spermine-treated pups (Tab. III). A significant decrease was also observed in the ileum for proteins, RNA, DNA, putrescine and spermidine.

\subsection{Spermine administration to weaned rats}

In weaned rats, $6 \mathrm{~h}$ after spermine administration, body weight $(46.75 \pm 1.39 \mathrm{~g}$ in controls vs. $45.50 \pm 1.50 \mathrm{~g}$ in treated; $n=5$ ) and organ weight remained unchanged (jejunum: $0.96 \pm 0.10 \mathrm{~g}$ in control vs. $0.89 \pm$ $0.10 \mathrm{~g}$ in treated; $n=5$ and ileum: $0.84 \pm$ $0.04 \mathrm{~g}$ in controls vs. $0.80 \pm 0.06 \mathrm{~g}$ in treated; $n=5$ ).

In 31-day-old rats, the RNA/DNA ratio (Tab. IV) remained unchanged after spermine administration as well as protein, RNA and DNA content in the jejunum (Tab. IV). In the ileum, these parameters were not affected by spermine ingestion, except for 
Table IV. Short-term effects of spermine administration in weaned (31 day-old) rats: protein, DNA and RNA content of the small intestine $6 \mathrm{~h}$ after spermine ingestion.

\begin{tabular}{|c|c|c|c|c|c|c|c|}
\hline & & \multirow{2}{*}{$\begin{array}{c}\text { Protein } \\
\mathrm{mg} \cdot \mathrm{g}^{-1} \text { wet } \\
\text { weight }\end{array}$} & \multicolumn{2}{|c|}{ DNA } & \multicolumn{2}{|c|}{ RNA } & \multirow[t]{2}{*}{ RNA/DNA } \\
\hline & & & $\begin{array}{l}\mathrm{mg} \cdot \mathrm{g}^{-1} \text { wet } \\
\text { weight }\end{array}$ & $\begin{array}{l}\mathrm{mg} \cdot \mathrm{g}^{-1} \\
\text { protein }\end{array}$ & $\begin{array}{l}\mathrm{mg} \cdot \mathrm{g}^{-1} \text { wet } \\
\text { weight }\end{array}$ & $\begin{array}{l}\mathrm{mg} \cdot \mathrm{g}^{-1} \\
\text { protein }\end{array}$ & \\
\hline \multirow[t]{2}{*}{ Jejunum } & Control $(n=3)$ & $113.8 \pm 17.2$ & $18.97 \pm 1.23$ & $169.7 \pm 31.6$ & $1.66 \pm 0.19$ & $14.83 \pm 3.55$ & $0.087 \pm 0.013$ \\
\hline & SPM-treated $(n=3$ & $117.5 \pm 9.5$ & $19.26 \pm 2.47$ & $165.7 \pm 35.8$ & $1.68 \pm 0.28$ & $14.44 \pm 3.62$ & $0.087 \pm 0.004$ \\
\hline \multirow[t]{2}{*}{ Ileum } & Control $(n=3)$ & $110.9 \pm 8.6$ & $17.62 \pm 0.32$ & $159.4 \pm 10.7$ & $1.64 \pm 0.05$ & $14.81 \pm 0.67$ & $0.093 \pm 0.002$ \\
\hline & SPM-treated $(n=3$ & $110.7 \pm 8.8$ & $18.99 \pm 0.74 *$ & $172.6 \pm 20.4$ & $1.57 \pm 0.06$ & $14.17 \pm 0.74$ & $0.082 \pm 0.007$ \\
\hline
\end{tabular}

$\mathrm{SPM}=$ spermine; the results are expressed as mean \pm S.D.; $* P<0.05$.

LACTASE SA

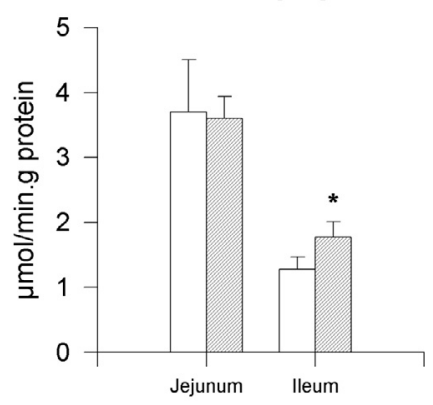

SUCRASE SA

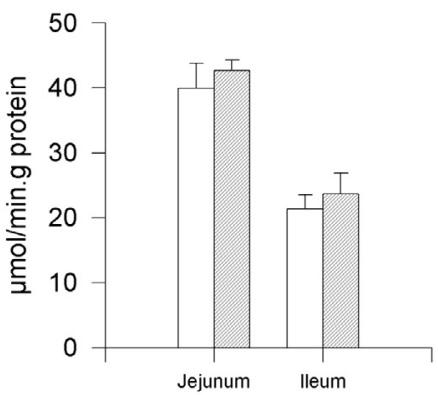

Control

spermine-treated

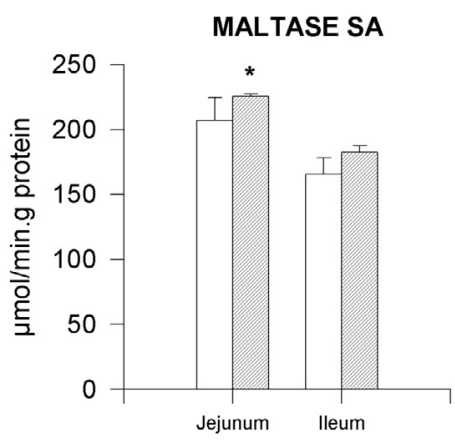

ALKALINE PHOSPHATASE SA

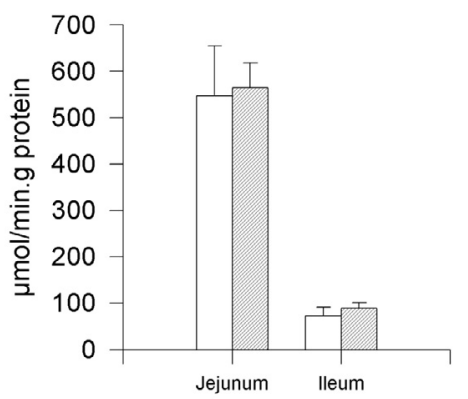

Figure 2. Disaccharidase and alkaline phosphatase SA in the small intestine of weaned (31-dayold) rats $6 \mathrm{~h}$ after spermine ingestion $(n=3)$. The results are expressed as mean \pm S.D.; $* P<0.05$.

the DNA content, which was slightly but significantly $(P=0.043)$ increased.

In these weaned rats, spermine administration affected neither lactase, sucrase or alkaline phosphatase SA in the jejunum, nor maltase, sucrase or alkaline phosphatase SA in the ileum (Fig. 2). In the jejunum, maltase SA and in the ileum, lactase SA were 
Table V. Short-term effects of spermine administration in weaned (31-day-old) rats: polyamine content of the small intestine $6 \mathrm{~h}$ after spermine ingestion.

\begin{tabular}{|c|c|c|c|c|c|c|c|}
\hline & & \multicolumn{2}{|c|}{ Putrescine } & \multicolumn{2}{|c|}{ Spermidine } & \multicolumn{2}{|c|}{ Spermine } \\
\hline & & $\begin{array}{c}\mathrm{nmol} \cdot \mathrm{g}^{-1} \\
\text { wet weight }\end{array}$ & $\begin{array}{l}\mu \mathrm{mol} \cdot \mathrm{g}^{-1} \\
\text { protein }\end{array}$ & $\begin{array}{c}\mathrm{nmol} \cdot \mathrm{g}^{-1} \\
\text { wet weight }\end{array}$ & $\begin{array}{c}\mu \mathrm{mol} \cdot \mathrm{g}^{-1} \\
\text { protein }\end{array}$ & $\begin{array}{c}\mathrm{nmol} \cdot \mathrm{g}^{-1} \\
\text { wet weight }\end{array}$ & $\begin{array}{c}\mu \mathrm{mol} \cdot \mathrm{g}^{-1} \\
\text { protein }\end{array}$ \\
\hline \multirow[t]{2}{*}{ Jejunum } & $\begin{array}{c}\text { Control } \\
(n=3)\end{array}$ & $282.4 \pm 72.2$ & $2.6 \pm 1.0$ & $1274 \pm 109$ & $11.4 \pm 8.8$ & $579.6 \pm 30.8$ & $5.17 \pm 0.81$ \\
\hline & $\begin{array}{l}\text { SPM-treated } \\
\quad(n=3)\end{array}$ & $254.2 \pm 33.5$ & $2.2 \pm 0.5$ & $1134 \pm 206$ & $9.6 \pm 4.5$ & $560.9 \pm 109.0$ & $4.75 \pm 0.63$ \\
\hline \multirow[t]{3}{*}{ Ileum } & Control $(n=3)$ & $225.4 \pm 53.1$ & $2.0 \pm 0.3$ & $1218 \pm 27$ & $11.0 \pm 0.6$ & $566.4 \pm 21.2$ & $5.12 \pm 0.30$ \\
\hline & $\begin{array}{l}\text { SPM-treated } \\
\quad(n=3)\end{array}$ & $321.5 \pm 87.9$ & $2.9 \pm 0.8$ & $1261 \pm 177$ & $11.4 \pm 1.1$ & $654.5 \pm 11.4 * *$ & $5.94 \pm 0.44$ \\
\hline & & nmol & $\%$ in ileum & nmol & $\%$ in ileum & nmol & $\%$ in ileum \\
\hline \multirow[t]{2}{*}{ Lumen } & Control $(n=3)$ & $70.4 \pm 26.8$ & $83.29 \pm 5.25$ & $241.3 \pm 70.3$ & $85.04 \pm 7.15$ & $59.3 \pm 11.2$ & $84.72 \pm 8.66$ \\
\hline & $\begin{array}{l}\text { SPM-treated } \\
\quad(n=3)\end{array}$ & $66.2 \pm 28.0$ & $84.93 \pm 1.60$ & $166.4 \pm 41.3$ & $88.45 \pm 3.36$ & $279.6 \pm 174.9^{* *}$ & $86.74 \pm 7.52$ \\
\hline
\end{tabular}

$\mathrm{SPM}=$ spermine; the results are expressed as mean \pm S.D.; $* * P<0.01$.

Table VI. Short-term effects of spermine administration in weaned (31-day-old) rats: quantity of protein, DNA, RNA, putrescine, spermidine and spermine per organ $6 \mathrm{~h}$ after spermine ingestion.

\begin{tabular}{|c|c|c|c|c|c|c|c|}
\hline & & $\begin{array}{c}\text { Protein } \\
\mathrm{mg} \cdot \text { organ }^{-1}\end{array}$ & $\begin{array}{c}\text { DNA } \\
\mathrm{mg} \cdot \text { organ }^{-1}\end{array}$ & $\begin{array}{c}\text { RNA } \\
\text { mg. } \text { organ }^{-1}\end{array}$ & $\begin{array}{c}\text { Putrescine } \\
\text { nmol-organ }^{-1}\end{array}$ & $\begin{array}{c}\text { Spermidine } \\
\text { nmol.organ }^{-1}\end{array}$ & $\begin{array}{c}\text { Spermine } \\
\text { nmol.organ }\end{array}$ \\
\hline \multirow[t]{2}{*}{ Jejunum } & Control $(\mathrm{n}=3)$ & $198.9 \pm 38.7$ & $34.6 \pm 12.3$ & $3.0 \pm 1.2$ & $531.4 \pm 59.9$ & $2327 \pm 830$ & $1050 \pm 343$ \\
\hline & SPM-treated $(n=3)$ & $234.6 \pm 34.8$ & $38.4 \pm 5.9$ & $3.3 \pm 0.7$ & $504.5 \pm 52.3$ & $2284 \pm 625$ & $1130 \pm 326$ \\
\hline \multirow[t]{2}{*}{ Ileum } & Control $(\mathrm{n}=3)$ & $211.9 \pm 11.0$ & $33.8 \pm 2.1$ & $3.1 \pm 0.2$ & $428 \pm 77$ & $2336 \pm 181$ & $1084 \pm 45$ \\
\hline & SPM-treated $(n=3)$ & $211.8 \pm 43.8$ & $36.2 \pm 6.2$ & $3.0 \pm 0.5$ & $531 \pm 80$ & $2395 \pm 182$ & $1249 \pm 193$ \\
\hline
\end{tabular}

$\mathrm{SPM}=$ spermine; the results are expressed as mean \pm S.D.

slightly but significantly increased (respectively $P=0.050$ and $P=0.048$ ) after spermine treatment.

Putrescine and spermidine contents of the jejunum and ileum were not affected by spermine administration (Tab. V). In the jejunum, spermine content remained unchanged after the treatment, but in the ileum, spermine content increased significantly when expressed as $\mathrm{nmol} \cdot \mathrm{g}^{-1}$ wet weight. In the lumen of the small intestine, putrescine and spermidine content were not affected by the administration of spermine. A significant increase of spermine was noticed in the lumen after this treatment. All the polyamines were mainly located in the lumen of the ileum, and the location was not affected by spermine administration.

When expressed as a weight per organ, protein, RNA, DNA, putrescine, spermidine and spermine remained unchanged in the jejunum and in the ileum after spermine ingestion (Tab. VI).

Disaccharidase activities were analysed in the jejunum and ileum of 11, 18, 20, 22 and 31 day old rats, $6 \mathrm{~h}$ after spermine ingestion (Fig. 3). The activities of disaccharidases were lower than the control in spermine-treated rats until the age of 20 days. 

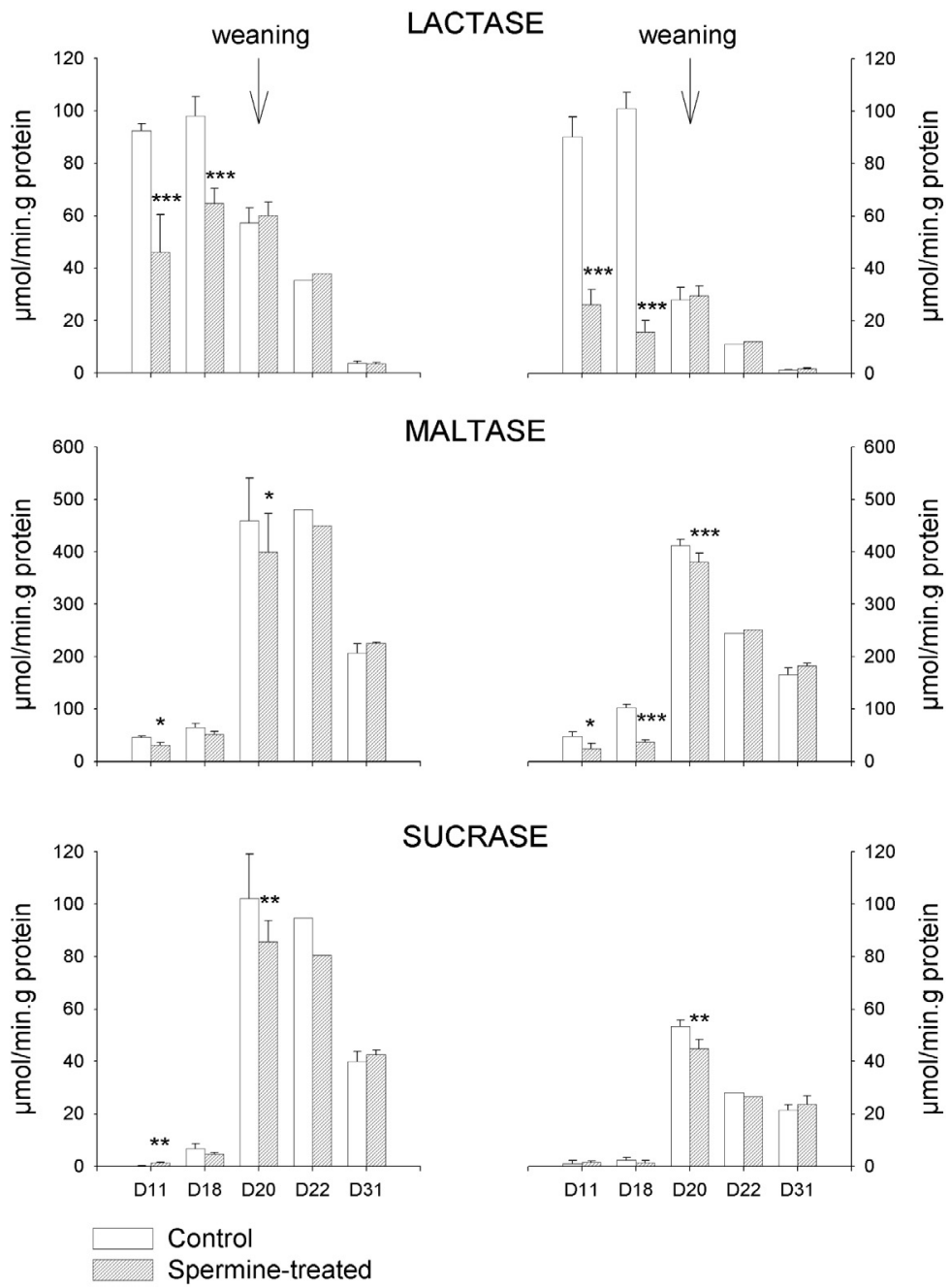

Figure 3. Lactase, maltase and sucrase SA in the jejunum (left panel) and ileum (right panel) of rats of different ages (D11, 11-day-old; D18, 18-day-old; D20, 20-day-old; D22, 22-day-old; D31, 31 -day-old) $6 \mathrm{~h}$ after spermine ingestion $(n=1$ for $\mathrm{D} 22, n=3$ for D11 and D $31, n=5$ for D18 and D20). The results are expressed as $\mu \mathrm{mol} / \mathrm{min} \cdot \mathrm{g}$ protein; $* P<0.05 ; * * P<0.01 ; * * * P<0.001$. Statistics were preformed using the Student-Newman-Keuls method.

\section{DISCUSSION}

Our results show that, $6 \mathrm{~h}$ after its ingestion, spermine $\left(0.4 \mu \mathrm{mol} \cdot \mathrm{g}^{-1}\right.$ body weight $)$ induced a drastic decrease of lactase and maltase SA in suckling rats (Fig. 1). This decrease occurred in the jejunum and in the ileum. A decrease of alkaline phosphatase was also observed in the ileum. Kaouass et al. [3] showed that a reduction of the villous height and a loss of epithelial cells occur $8 \mathrm{~h}$ after spermine administration. 
This loss is accompanied by an increase of lactase and maltase SA in the chyme. However these authors did not estimate sucrase SA [3]. In our study, we show that sucrase SA was increased after spermine administration. We hypothesise that this fact is due to the localisation of the enzyme in the crypt-villous axis. Indeed, in situ hybridisation showed that sucrase-isomaltase mRNA is located at the crypt-villous junction and in the lower to mid-villous region [13]. If the upper part of the villous is removed by spermine treatment, the activity of this enzyme expressed per organ is the same, but its SA is increased. We suggest that the decrease of the alkaline phosphatase SA is also due to the reduction of the villous height, already demonstrated by the decrease of lactase and maltase SA.

In 31-day-old rats, spermine administration did not change intestinal enzymatic parameters, except slightly for lactase and maltase (respectively $P=0.050$ and $P=$ 0.048) (Fig. 2). These changes do not suggest a cell loss of the small intestine, since there was an increase of the SA.

If a cell loss occurs in the small intestine, all biochemical parameters (protein, DNA...) are influenced by the phenomenon. Thus, the best reference to study the cell loss is the organ itself, while the best reference to study intracellular events is probably the protein or DNA content. In suckling rats, the protein, DNA, RNA, putrescine and spermidine content, expressed as weight per organ (Tab. III), as well as the organ wet weight itself, decreased drastically after spermine ingestion. These decreases support a loss of cells in the intestinal lumen, a phenomenon already proven by histological observations [1-3].

The spermine content of the organ remained unchanged, suggesting that the spermine ingestion and the subsequent uptake of this molecule by the surviving cells hide the loss of spermine in the lumen. Indeed, luminal spermine uptake by enterocytes has already been largely documented [14]. This uptake and the subsequent transport in the portal vein are rapid $(<1 \mathrm{~min})$, as shown in an exvivo model of the rat small intestine [15] and in a rabbit isolated brush border membrane model [16]. In the rabbit, the brush border membrane contains several ligand specific sites for polyamine binding [17] probably involved in the uptake of these compounds. However, to our knowledge, no differences have been described between suckling and weaned rats regarding polyamine uptake.

The increase of the spermine content in the lumen and its main location in the ileum (Tab. II) supports the hypothesis that the exogenous polyamine was in the intestinal lumen and had already passed through the jejunum. The spermine absorption by surviving cells is supported by the increase of spermine content, expressed as $\mu \mathrm{mol}$ per $\mathrm{g}$ protein (Tab. II). In weaned 31-day-old rats, all these parameters (protein, DNA, RNA, putrescine and spermidine content expressed as weight per organ) remained unchanged (Tab. VI), suggesting that the small intestine keeps its integrity even if spermine has reached the lumen of the small intestine, as shown by the increase of spermine content in the lumen.

Spermine-induced cell loss is not due to cytotoxic products [18] coming from the metabolisation of spermine by polyamine oxidase [3]. Indeed, pre-treatment with MDL72527, a polyamine oxidase inhibitor, does not reduce the cell loss. Cytotoxic products could come from diamine oxidase activity. However, the activity of this enzyme is very weak in the small intestine mucosa of sucklings [19]. The cell loss could also be due to: (1) a secondary agent, such as TNF- $\alpha[20,21]$ or corticosterone [22], observed in plasma shortly after spermine ingestion [23, 24], (2) apoptosis directly induced by spermine [25-29] or (3) cell detachment from the basal membrane by activation collagenase [30]. In a previous study, we showed that the activation of metalloproteinase is the most likely hypothesis [5]. Meprin, a zinc-metalloendopeptidase, is a good candidate, since it is expressed 
in intestinal epithelial cells [31] and in lamina propria leukocytes [32]. Moreover, before weaning, meprin expression is induced by glucocorticoids [33]. Meprin is classified in the astacin family of metalloendopeptidases containing an HEXXHXXGFXHE zincbinding motif [34]. Based on other members of the astacin family, proposed functions include the degradation of extracellular matrix proteins $[35,36]$ and the regulation of the development $[37,38]$. The metalloproteinase involved could also be contained in the milk [39].

Analyses of disaccharidase activities $6 \mathrm{~h}$ after spermine ingestion in rats from 11 to 31 days old (Fig. 3) show that spermineinduced cell loss is age-dependent. Cell loss stops occurring at weaning time (20 days).

This difference between suckling and weaned rats can be explained by the natural decline of the meprin alpha subunit after weaning [40] or by the cessation of milk intake. However, at this point we are unable to exclude a specific intrinsic sensitivity of the cells due to polyamine uptake or metabolism. Indeed, ODC activity is increased during natural weaning $[19,41]$ and precocious weaning [42], leading to an increase of polyamine concentration in cells. The accumulation of dietary and exogenous polyamine could induce cell death [26]. However, other information regarding the difference in polyamine metabolism between suckling and weaned rats is not available.

In conclusion, 31-day-old rats are not sensitive to exogenous spermine, as are suckling rats. This could be explained by a proteinase-mediated process or by an accumulation of polyamine inside the cell of the suckling.

\section{ACKNOWLEDGMENTS}

Authors are indebted to the Leon-Fredericq foundation from Liege University for its support.

\section{REFERENCES}

[1] Wery I, Deloyer P, Dandrifosse G. Effects of a single dose of orally administered spermine on the intestinal development of unweaned rats. Arch Physiol Biochem 1996, 104: 163172.

[2] Peulen O, Pirlet C, Klimet M, Goffinet G, Dandrifosse G. Comparison between the natural postnatal maturation and the spermineinduced maturation of the rat intestine. Arch Physiol Biochem 1998, 106: 46-55.

[3] Kaouass M, Deloyer P, Wery I, Dandrifosse G. Analysis of structural and biochemical events occurring in the small intestine after dietary polyamine ingestion in suckling rats. Dig Dis Sci 1996, 41: 1434-1444.

[4] Peulen O, Dandrifosse G. Cyclosporine A inhibits partially spermine-induced differentiation but not cell loss of suckling rat small intestine. Dig Dis Sci 2000, 45: 750-754.

[5] Peulen O, Denis G, Defresne MP, Dandrifosse G. Spermine-Induced alteration of small intestine in suckling rat: involvement of apoptosis or $\mathrm{Zn}^{2+}$ enzymes? Dig Dis Sci 2001, 46: 2490-2498.

[6] Dufour C, Dandrifosse G, Forget P, Vermesse F, Romain N, Lepoint P. Spermine and spermidine induce intestinal maturation in the rat. Gastroenterology 1988, 95: 112-116.

[7] Bradford MM. A rapid and sensitive method for the quantitation of microgram quantities of protein utilizing the principle of protein-dye binding. Anal Biochem 1976, 72: 248-254.

[8] Dahlqvist A. Method for assay of intestinal disaccharidases. Anal Biochem 1964, 7: 18-25.

[9] Millington PF, Tovell PW. Quantitative changes in alkaline phosphatase in epithelial cells of rat small intestine from birth to weaning. Histochem J 1969, 1: 311-321.

[10] Schneider WC. Determination of nucleic acids in tissues by pentose analysis. Methods Enzymol 1957, 3: 680-684.

[11] Bontemps J, Laschet J, Dandrifosse G, Van Cutsem JL, Forget PP. Analysis of dansyl derivatives of di- and polyamines in mouse brain, human serum and duodenal biopsy specimens by high- performance liquid chromatography on a standard reversed-phase column. J Chromatogr 1984, 311: 59-67.

[12] Brown ND, Strickler MP, Whaun JM. Femtomolar ion-pair high-performance liquid chromatographic method for determining Dnspolyamine derivatives of red blood cell extracts utilizing an automated polyamine analyzer. J Chromatogr 1982, 245: 101-108.

[13] Traber PG. Regulation of sucrase-isomaltase gene expression along the crypt- villus axis of 
rat small intestine. Biochem Biophys Res Commun 1990, 173: 765-773.

[14] Milovic V. Polyamines in the gut lumen: bioavailability and biodistribution. Eur J Gastroenterol Hepatol 2001, 13: 1021-1025.

[15] Uda K, Tsujikawa T, Fujiyama Y, Bamba T. Rapid absorption of luminal polyamines in a rat small intestine ex vivo model. J Gastroenterol Hepatol 2003, 18: 554-559.

[16] Milovic V, Stein J, Piiper A, Gerhard R, Zeuzem S, Caspary WF. Characterization of putrescine transport across the intestinal epithelium: study using isolated brush border and basolateral membrane vesicles of the enterocyte. Eur J Clin Invest 1995, 25: 97-105.

[17] Brachet P, Long JE, Siedel ER. Selective sites for polyamine binding to rabbit intestinal brush-border membranes. Biochem Pharmacol 1998, 56: 517-526.

[18] Morgan DM. Polyamines and cellular regulation: perspectives. Biochem Soc Trans 1990, 18: $1080-1084$

[19] Luk GD, Marton LJ, Baylin SB. Ornithine decarboxylase is important in intestinal mucosal maturation and recovery from injury in rats. Science 1980, 21: 195-198.

[20] Tracey KJ, Beutler B, Lowry SF, Merryweather J, Wolpe S, Milsark IW, Hariri RJ, Fahey TJ, Zentella A, Albert JD, Shires GD, Cerami A. Shock and tissue injury induced by recombinant human cachectin. Science 1986, 234 : 470-474.

[21] Remick DG, Kunkel RG, Larrick JW, Kunkel SL. Acute in vivo effects of human recombinant tumor necrosis factor. Lab Invest 1987, 56: 583-590.

[22] Wyllie AH. Glucocorticoid-induced thymocyte apoptosis is associated with endogenous endonuclease activation. Nature 1980, 284: $555-556$.

[23] Kaouass M, Sulon J, Deloyer P, Dandrifosse G. Spermine-induced intestinal postnatal maturation: are glucocorticoids necessary? Arch Int Physiol Biochim Biophys 1992, 101: B118.

[24] Kaouass M, Sulon J, Deloyer P, Dandrifosse G. Spermine-induced precocious intestinal maturation in suckling rats: possible involvement of glucocorticoids. J Endocrinol 1994, 141: 279-283.

[25] Dypbukt JM, Ankarcrona M, Burkitt M, Sjoholm A, Strom K, Orrenius S, Nicotera P. Different prooxidant levels stimulate growth, trigger apoptosis, or produce necrosis of insu- lin-secreting RINm5F cells. The role of intracellular polyamines. J Biol Chem 1994, 269: 30553-30560.

[26] Poulin R, Pelletier G, Pegg AE. Induction of apoptosis by excessive polyamine accumulation in ornithine decarboxylase-overproducing L1210 cells. Biochem J 1995, 311: 723 727 .

[27] Hu RH, Pegg AE. Rapid induction of apoptosis by deregulated uptake of polyamine analogues. Biochem J 1997, 328: 307-316.

[28] Stefanelli C, Bonavita F, Stanic I, Mignani M, Facchini A, Pignatti C, Flamigni F, Caldarera CM. Spermine causes caspase activation in leukaemia cells. FEBS Lett 1998, 437: 233236.

[29] Stefanelli C, Bonavita F, Stanic' I, Pignatti C, Flamigni F, Guarnieri C, Caldarera CM. Spermine triggers the activation of caspase- 3 in a cell-free model of apoptosis. FEBS Lett 1999, 451: 95-98.

[30] Mendizabal MV, Naftalin RJ. Effect of spermine on water absorption, polyethylene glycol 4000 permeability and collagenase activity in rat descending colon in vivo. Clin Sci 1992, 83: 417-423.

[31] Sterchi EE, Naim HY, Lentze MJ, Hauri HP, Fransen JAM. N-benzoyl-L-tryosyl-P-aminobenzoic acid hydrolase - A metalloendopeptidase of the human intestinal microvillus membrane which degrades biologically-active peptides. Arch Biochem Biophys 1988, 265: $105-118$

[32] Lottaz D, Hahn D, Muller S, Sterchi EE. Secretion of human meprin from intestinal epithelial cells depends on differential expression of the alpha and beta subunits. Eur J Biochem 1999, 259: 496-504.

[33] Henning SJ, Oesterreicher TJ, Osterholm DE, Lottaz D, Hahn D, Sterchi EE. Meprin mRNA in rat intestine during normal and glucocorticoid-induced maturation: divergent patterns of expression of alpha and beta subunits. FEBS Lett 1999, 462: 368-372.

[34] Dumermuth E, Sterchi EE, Jiang WP, Wolz RL, Bond JS, Flannery AV, Beynon RJ. The astacin family of metalloendopeptidases. J Biol Chem 1991, 266: 21381-21385.

[35] Kaushal GP, Walker PD, Shah SV. An Old Enzyme with A New Function - Identification of the distinct matrix-degrading metalloproteinase in rat-kidney cortex as meprin-A. J Am Soc Nephrol 1994, 5: 810.

[36] Lottaz D, Maurer CA, Hahn D, Buchler MW, Sterchi EE. Nonpolarized secretion of human 
meprin alpha in colorectal cancer generates an increased proteolytic potential in the stroma. Cancer Res 1999, 59: 1127-1133.

[37] Suzuki N, Labosky PA, Furuta Y, Hargett L, Dunn R, Fogo AB, Takahara K, Peters DM, Greenspan DS, Hogan BL. Failure of ventral body wall closure in mouse embryos lacking a procollagen $\mathrm{C}$-proteinase encoded by $\mathrm{Bmp} 1$, a mammalian gene related to Drosophila tolloid. Development 1996, 122: 3587-3595.

[38] Goodman SA, Albano R, Wardle FC, Matthews G, Tannahill D, Dale L. BMP1-related metalloproteinases promote the development of ventral mesoderm in early Xenopus embryos. Dev Biol 1998, 195: 144-157.

[39] Cheung PY, Sawicki G, Gross S, Van Aerde J, Radomski M. Differential expression of matrix metalloproteinases and the tissue inhibitor in human milk. Proc West Pharmacol Soc 2001, 44: 97-98.

[40] Kumar JM, Bond JS. Developmental expression of meprin metalloprotease subunits in ICR and $\mathrm{C} 3 \mathrm{H} / \mathrm{He}$ mouse kidney and intestine in the embryo, postnatally and after weaning. Biochim Biophys Acta 2001, 1518: 106-114.

[41] Riby JE, Hurwitz RE, Kretchmer N. Development of ornithine metabolism in the mouse intestine. Pediatr Res 1990, 28: 261-265.

[42] Lin CH, Correia L, Tolia K, Gesell MS, Tolia V, Lee PC, Luk GD. Early weaning induces jejunal ornithine decarboxylase and cell proliferation in neonatal rats. J Nutr 1998, 128: 1636-1632. 